\title{
The Synthesis and Evaluation of Vanillin derivatives as the Fruit Fly Attractant
}

\author{
SUSY YUNITA PRABAWATI ${ }^{\text {* }}$, DAMAYANTI ISKANDAR ${ }^{1}$ and LIIMROATI PURWO SUCI ${ }^{1}$ \\ ${ }^{1}$ Department of Chemistry, Faculty of Science and Technology, Universitas Islam Negeri Sunan Kalijaga \\ Jl. Marsda Adisucipto, Yogyakarta 55281 Indonesia. \\ *Corresponding author E-mail: susyprabawati@gmail.com
}

http://dx.doi.org/10.13005/ojc/3404063

(Received: June 08, 2018; Accepted: July 20, 2018)

\begin{abstract}
The present study was conducted to synthesize 4-(4-hydroxyphenyl-3-methoxy)-4-hydroxy2-butanone, a compound with similar structure to cue lure [4-(4-Acetyoxyphenyl)-2-butanone], using vanillin as a started material. The synthesis process was completed in two steps. The first step was the condensation reaction of Claisen Smidth between vanillin and acetone on alkaline conditions to produce 4-(4-hydroxyphenyl-3-methoxy)-3-buten-2-one, and the second step was the hydration reaction using zeolite catalysts activated by $\mathrm{HCl}$, to produce 4-(4-hydroxyphenyl-3-methoxy)4-hydroxy-2-butanone. Characterization of the compounds was performed using IR and ${ }^{1} \mathrm{H}-\mathrm{NMR}$ spectroscopy. The evaluation of 4-(4-hydroxyphenyl-3-methoxy)-4-hydroxy-2-butanone as fruit flies' attractant was carried out in yard areas planted with guava and start fruit, in the Klidon village, Sukoharjo, Sleman Yogyakarta, with methyl eugenol as a standard. The observations were made for 24 hours. The synthesis product was obtained in the form of a white-orange solid with a melting point of $79-81^{\circ} \mathrm{C}$ and $60 \%$ yield. The field test showed that 4-(4-hydroxyphenyl-3-methoxy)-4-hydroxy2-butanone was potential as fruit flies' attractant, indicated by the presence of lured fruit flies around the test location.
\end{abstract}

Keywords: 4-(4-hydroxyphenyl-3-methoxy)-4-hydroxy-2-butanone, Attractant, Cue lure, Canilin.

\section{INTRODUCTION}

The post-harvest treatment of fruits to control fruit flies attack usually involve the use of synthetic pesticides. The most frequent and damaging fruits flies for fruit harvest in Indonesia is Bactrocera spp (Diptera: Tephritidae) ${ }^{1}$.
It has been known widely that using pesticide continuously will impose a serious negative impact on the environment. In addition, consuming fruits treated with pesticide may lead to the accumulation of pesticide residues in body. ${ }^{2}$ One of the most easy and efficient alternative solutions to control fruit flies is using traps baited with attractant.

This is an Open Access article licensed under a Creative Commons Attribution-Non Commercial-Share Alike 4.0 International License (https://creativecommons.org/licenses/by-nc-sa/4.0/), which permits unrestricted Non Commercial use, distribution and reproduction in any medium, provided the original work is properly cited. 
Some attractant compounds that have been studied, such as methyl eugenol (4-(4-Allyl-1. 2-dimetoxybenzena), cue lure (4-(4-Asetoxyphenyl)2-butanone) (Fig. 1a), and raspberry ketones (4-(4-Hydroxyphenyl)-2-butanone), are identified as strong parapheromones to attract male fruit flies. Those synthetic compounds have been experimented with to monitor, detect and control fruit flies. ${ }^{3}$ The results show that a total of 176 species of Dacinea male fruit flies are attracted to cue lure/raspberry ketone, and 58 species are lured to methyl eugenol. ${ }^{4}$

However, a certain species of male fruit flies is basically interested in specific attractant or parapheromone. ${ }^{5}$ For example, the male melon fruit fly (B. cucurbitae) is attracted to 4-(4-Hydroxyphenyl)-3butene-2-one, an intermediate compound of cue lure.

Apparently, with a considerable amount of fruit fly species, the type of attractant or parapheromone that is specifically attractive to particular fruit fly species have not been completely studied. Therefore, the continuing study of cue lure, an analog of naturally occurring ketone raspberry is required to control fruit flies.

In this study, a compound with similar structure to vanillin cue lure, namely 4-(4-hydroxy phenyl3-methoxy)-4-hydroxy-2-butanone (Fig. 1b), was synthesized.<smiles>CC(=O)CCc1ccc(OC(C)=O)cc1</smiles>

Fig. 1a. The structure of cue lure<smiles>COc1cc(C(O)CC(C)=O)ccc1O</smiles>

Fig. 1b. The structure of 4-(4-hydroxyphenyl-3-methoxy)-4hydroxy-2-butanone

Vanillin is a compound containing aldehyde groups that can undergo aldol condensation when reacted with acetone in alkaline condition. The reaction that occurs is shown in Figure 2.

The initial research conducted by Suci et al., ${ }^{6}$ shows that the 4-(4-Hydroxyphenyl-3 -methoxy)-3-buten-2-one is potential as an attractant because it can capture one fruit fly on chili. It seems that the existence of a functional group-OH instrumental in increasing its activities as an attractant.

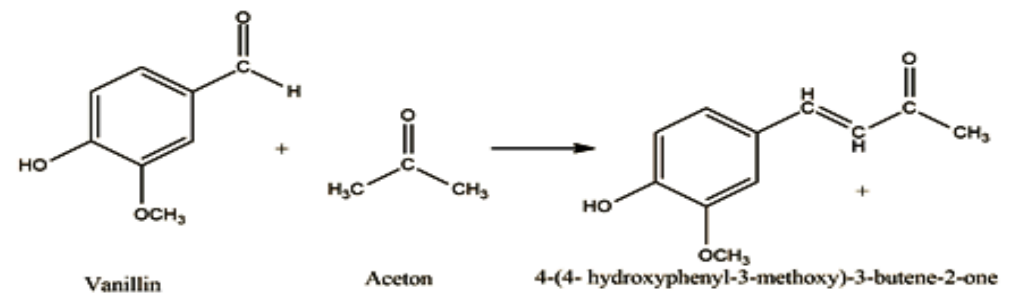

Fig. 2. The aldol condensation of vanillin with acetone

To obtain the compound with similar structure to cue lure, the hydration reaction to break the double bond on 3-butene-2-one group has been conducted and resulting in 4-(4-hydroxyphenyl-3 -methoxy)-4-hydroxy-2-butanone. The addition of $-\mathrm{OH}$ group is expected to further enhance the activity of the compound as the attractant for fruit flies.

\section{MATERIALS AND METHODS}

\section{Materials}

The materials used in this study consisted of vanillin, $\mathrm{NaOH}$, aquadest, acetone, ethanol, $\mathrm{HCl}$, chloroform, ethyl acetate, $\mathrm{Na}_{2} \mathrm{SO}_{4}$ anhidrous, and zeolite. All materials were analytical grade (E-Merck), except for aquadest and aluminum foil.

\section{Tools}

The tools used in this research were chemistry glassware set, hot plate, analytical balance, 
spatula, magnetic stirrer, ${ }^{1} \mathrm{HNMR}$ spectroscopy (Agilent Teknologies $500 \mathrm{MHz}$ ), FTIR spectroscopy (SHIMADZU), UV-Vis spectrophotometer (SHIMADZU $\mathrm{U}-1800)$, and melting point apparatus.

\section{Procedures}

The synthesis of 4-(4-Hydroxyphenyl-3-methoxy)3-buten-2-one

In a $250 \mathrm{~mL}$ erlenmeyer flask equipped with an ice bath, $7.8 \mathrm{~mL}(0.1052 \mathrm{~mol})$ of acetone were mixed with $4 \mathrm{~mL}$ of $30 \% \mathrm{NaOH}$ using magnetic stirrer for 30 minutes. Then, the mixture was added with $2 \mathrm{~g}(0.0131 \mathrm{~mol})$ of vanillin at room temperature. The obtained sediment was added with $15 \mathrm{~mL}$ of ethanol, stirred for $1 \mathrm{~h}$ and then left for 24 hours. Next, the mixture was added with $20 \mathrm{~mL}$ of cold water and $15 \mathrm{~g}$ of ice, mixed for $30 \mathrm{~min}$. and then acidified with $10 \% \mathrm{HCl}$. Afterwards, the solution was extracted three times with $25 \mathrm{~mL}$ of chloroform. The organic phase was then washed with $25 \mathrm{~mL}$ of aquadest, followed by the addition of $\mathrm{Na}_{2} \mathrm{SO}_{4}$ anhidrous. Lastly, the solution was filtered and evaporated until a solid substance was obtained.

\section{The synthesis of 4-(4-hydroxyphenyl-3-methoxy)-} 4-hydroxy-2-butanone.

First, $1 \mathrm{~g}$ of 4-(4-Hydroxyphenyl-3-methoxy) -3-buten-2-one, $10 \mathrm{~mL}$ aquabidest and $13.6 \mathrm{~mL}$ ethanol were loaded into a three-neck rounded flask. The mixture was refluxed until the temperature reached $30^{\circ} \mathrm{C}$. Afterwards, $0.5 \mathrm{~g}$ of zeolite catalyst was added and the mixture was refluxed for 120 minutes.

The evaluation of 4-(4-hydroxyphenyl-3-methoxy)4-hydroxy-2-butanone as attractant

Three Steiner traps containing cottons wetted by four liquid drops of synthesized 4-(4-hydroxyphenyl-3-methoxy group)-4-hydroxy -2-butanon were prepared. The traps were placed in yard areas planted with guava and start fruit, in the Klidon village, Sukoharjo, Sleman Yogyakarta. After $24 \mathrm{~h}$ the trapped fruit flies were counted. The presence of fruit files in the test area was previously confirmed with the installation of methyl eugenol as a positive control.

\section{RESULTS AND DISCUSSION}

The synthesis results of 4-(4-Hydroxyphenyl-3methoxy)-3-buten-2-one

The synthesis of 4-(4-Hydroxyphenyl-3- methoxy)-3-buten-2-one was carried out through aldol condensation reaction, which involved an addition of nucleophilic enolate ion from acetone on aldehyde group in vanillin. The method referred to the research conducted by Pranowo et al., ${ }^{7}$ in a 1:8 mol ratio of vanillin and acetone, and with $30 \% \mathrm{NaOH}$ as a catalyst. The product obtained was some yellow colored needle-shaped crystals, with a melting point of $77-78^{\circ} \mathrm{C}$. The mechanisms that occur was shown in Figure 3.

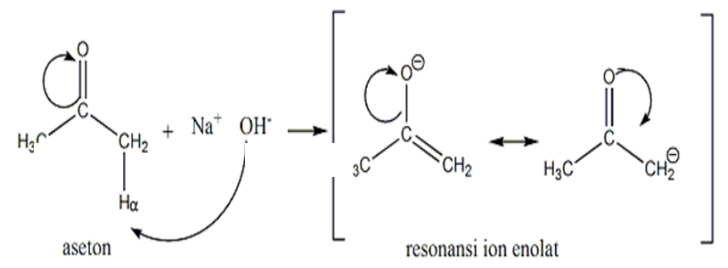<smiles>[CH2+]OCC(=O)CCCCC[C@@H]1OC[C@H]1c1ccc(O)c(OC)c1</smiles><smiles>COc1cc([C@@H](O)CC(C)=O)ccc1O</smiles>

4-(Hidroksifenil-3-metoksi)-3-buten-2-on

Fig. 3. Aldol condensation reaction mechanism

The results of IR spectrum analysis showed the forming of ketone groups from 4-(4-Hydroxyphenyl-3-methoxy)-3-buten-2-one. It was characterized by the shifting of absorption from $2561.47 \mathrm{~cm}^{-1}$ wavenumbers, the specific vibration range for aldehyde $\mathrm{C}-\mathrm{H}$ group in vanillin, to $2569.18 \mathrm{~cm}^{-1}$, the typical absorption of C-C group after ketone group inclusion. In addition, a specific absorption for aromatic compound at 1589.34 $\mathrm{cm}^{-1}$ and $1512.19 \mathrm{~cm}^{-1}$, also for methoxy group at $1100-1300 \mathrm{~cm}^{-1}$ were observed.

The synthesis results of 4-(4-hydroxyphenyl-3methoxy)-4- hydroxy-2-butanone

The synthesis of 4-(4-hydroxy-phenyl-3methoxy)-4-hydroxy-2-butanone was conducted through the hydration reaction of 4-(4-Hydroxyphenyl3-methoxy)-3-buten-2-one, using zeolite catalysts. 
The reaction was intended to break double bonds in 3-buten-2-one functional group, so that the final structure of the compound was similar to the structure of cue lure, which had previously been shown to act as fruit fly attractant. The reaction that occurs was shown in Figure 4.

The double bond was broken to form new single bond, and hydroxyl group was bonded to $\mathrm{C}$ atom. As a result, the final compound contains two hydroxyl groups, the probably active groups in attractant.

Analysis by FTIR spectroscopy resulted in a spectrum shown in Fig. 5. The forming of hydration reaction product, was confirmed with the presence of aliphatic $\mathrm{C}-\mathrm{H}$ absorption, which appeared sharper on $2939.52 \mathrm{~cm}^{-1}$ wavenumbers. In addition, the absorption of $-\mathrm{OH}$ group was shifted toward $3448.72 \mathrm{~cm}^{-1}$ wavenumbers.

Further identification with ${ }^{1} \mathrm{HNMRspectroscopy}$ produced a spectrum shown in Figure 6.

Based on the spectrum, there were four distinct proton environments. The first peak appeared at $2.3 \mathrm{ppm}$, the chemical shift of protons on hydrogen

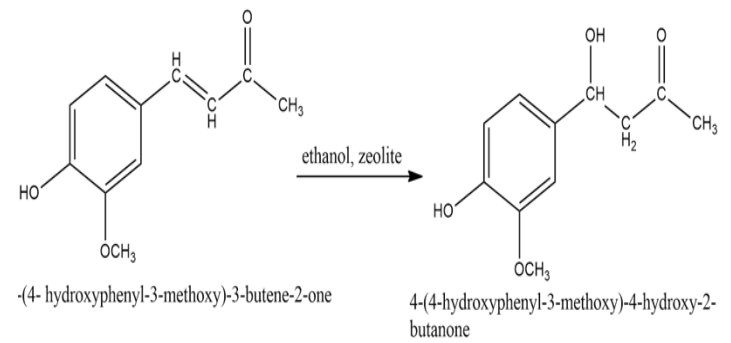

Fig. 4. The hydration reaction of 4-(4-hydroxyphenyl-3 -methoxy)-3-buten-2-one

atoms of the carbon that attached to the ketone group (alpha carbon). This was confirmed by the result of FTIR spectrum analysis that shown the shift of $\mathrm{C}-\mathrm{C}$ wavenumber from ketone group, as indicated by the absorption of carbonyl group from ketone at $2569.18 \mathrm{~cm}^{-1}$ wavenumbers.

The second peak appeared on the chemical shift of $3.9 \mathrm{ppm}$, indicated the absorption of proton on methoxy group that bonded to benzene. A methoxy group was very easily detected because the group appeared on the specific shift area of 3.2-3.8 ppm, and a high singlet peak indicated the existence of methoxy $\left(\mathrm{O}-\mathrm{CH}_{3}\right)$ compound. ${ }^{8}$ The third peak appeared on the chemical shift of 6,7-7.3 ppm, the specific absorption area of proton-proton on benzene ring. The absorption appeared in multiplet.

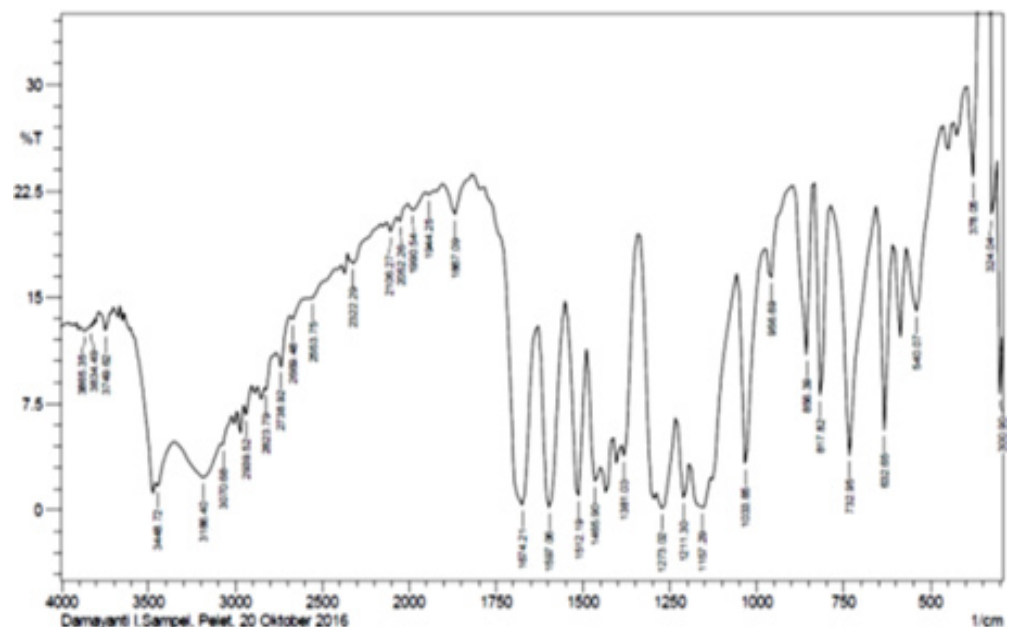

Fig. 5. The FTIR spectrum of 4-(4-hydroxyphenyl-3-methoxy group)-4-hydroxy-2-butanone

The last peak that appeared at 9.8 ppm was the peak resulted from a hydroxyl proton bonded to carbon group in the para position from phenol group. The chemical shift of hydroxyl group appeared on the upfield (more protected than hydroxyl groups bonded to benzene ring (12.05 ppm)) due to the exixtence of carbon atoms, the electron donor groups. Therefore, the hydrogen peak appeared in the more protected shift. A substitution of hydroxyl group from alkenes bonded to benzene group, had been successfully done. This was verified by the absence of peak on the chemical shift area of 5.3-5.9 ppm, the shift area of alkene protons that attached to benzene group. ${ }^{8}$ 


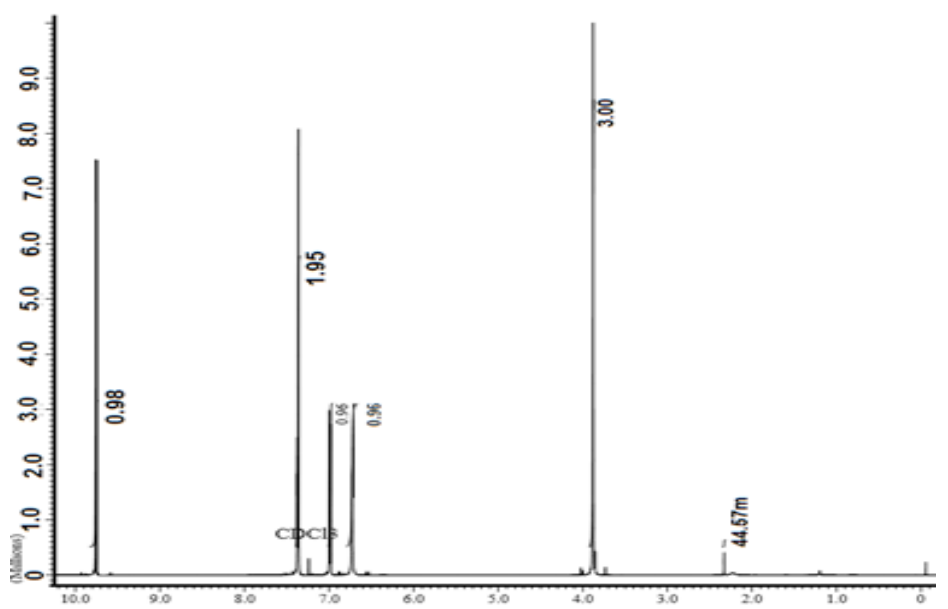

Fig. 6. The ${ }^{1}$ HNMR spectrum of 4-(4- hydroxyphenyl-3-methoxy)-4-hydroxy-2-butanone

The fruit flies activity assay of 4-(4-hydroxyphenyl3-methoxy group)-4-hydroxy-2-butanone

The number of fruit flies attracted to methyl eugenol (as control) and 4-(4-hydroxyphenyl -3-methoxy)-3-Hydroxy-2-butanone was presented in Table 1.

The results showed that the synthesized compound had potential as an attractant for fruit flies, as indicated by the presence of fruit flies on 4-(4-hydroxyphenyl-3-methoxy)-4-hydroxy-2 -butanone, prior to the installation on Steiner pitfalls.

From the data in Table 1, the number of fruit flies attracted to the synthesized compound was much less compared to methyl eugenol. This is possibly because the concentration of 4-(4-hydroxyphenyl-3-methoxy)-4-hydroxy-2butanon is not high enough to be detected by fruit flies at a far distance area.

Table 1: Test results of fruit flies attractant compound in pool

\begin{tabular}{llc}
\hline No & The type of attractant & $\begin{array}{c}\text { The total number } \\
\text { of fruit flies }\end{array}$ \\
\hline 1 & Methyl Eugenol & 16 \\
2 & $\begin{array}{l}\text { 4-(4-hydroxy-phenyl-3-methoxy) } \\
\text {-4-hydroxy-2-butanone }\end{array}$ & 3 \\
\hline
\end{tabular}

Muryati et al., ${ }^{9}$ have studied the identification of many fruit flies species and their responses to attractant made from methyl eugenol and cue lure. It turns out that the species of $B$. albistrigata, B. cucurbitae, and B. knowmore are interested in cue lure, while the species of $B$. carambolae and $B$. papayae on chilies and papaya as their host plants, can only be caught by methyl eugenol. In this study, the presence of fruit flies that flock and resting on the synthesized compound indicates the presence of fruit fly species that corresponds to the compound. Further research is needed to identify those fruit flies' species that attracted to 4-(4-hydroxyphenyl -3-methoxy)-4-hydroxy-2-butanone.

\section{CONCLUSION}

A compound with similar structure to cue lure, namely 4-(4-hydroxyphenyl-3-methoxy) -4-hydroxy-2-butanon has been successfully synthesized through condensation reaction between vanillin and acetone in alkaline condition $(\mathrm{NaOH} 30 \%)$, followed by the hydration reaction using zeolite as catalyst with a yield of $60 \%$. The field test shows that the 4-(4- hydroxyphenyl -3-methoxy) -4-hydroxy-2-butanone is a potential attractant for fruit flies.

\section{ACKNOWLEDGEMENT}

Thanks to the LPPM UIN Sunan Kalijaga Yogyakarta for the research funding provided through the HAKI Research Grants in 2016.

\section{REFERENCES}

1. Kalshoven, L.G.E., Pest of Crops in Indonesia. Revised and Traslated by Van der Loan.,
Jakarta: Ichtiar Baru Van Hoeve., 1981.

2. Rahmawati, Y.P. Ketertarikan Lalat Buah 
Bactrocera sp. Pada Senyawa Atraktan Yang Mengandung Campuran Protein Dan Metil Eugenol. Skripsi. Fakultas Matematika dan IImu Pengetahuan Alam. Universitas Negeri Semarang. Semarang., 2014, 1-2, 31-32.

3. Vargas, R. I., J.D. Stark, M. H. Kido, H.M. Ketter, and L. C.Whitehand. Methyl eugenol and cuelure traps for suppression of male oriental fruit flies and melon flies (Diptera: Tephritidae) in Hawaii: effects of lure mixtues and weathering. J. Econ. Entomol., 2000. 93, 81-87.

4. Metcalf, R. L. and E. R. Metcalf.. Fruit Bies Of The Family Tephritidae. In Plant Kairomones In Insect Ecologyand Control. R. L. Metcalf and E. R. Metcalf [eds.]Routledge, Chapman \& Hall. New York., 1992.

5. Pranowo, Suputra, Wahyuningsih T. D., Synthesis of 4-(3,4-dimethoxy-phenil)-3- butene-2-on And Activity Its Test as A Fruit Flies Attractant. Indo. J. Chem., 2006, 6(1), 99-103.

6. Suci. L.P., Prabawati, S.Y., Sintesis 4-(4hidroksifenil-3-metoksi)-3-Buten-2-on dari Vanilin sebagai Attractant Lalat Buah, diseminarkan pada Seminar Nasional HKI, 2016, Bandung, 4 Agustus 2016.

7. Pranowo, Affandi M.Y., Chandraningrum.W, Muchalal.M,. Mempelajari Sintesis 4-(Hidroksi Fenil)-3-Buten-2-On. Prosiding (SN-KPK II). 2010, 10, 93-95.

8. Pavia.D.L., Lampman.G.M., Kriz.G.S., Vyyyan.J.R.. Introduction to Spectroscopy. Fourth Edition. USA. Pre Press PMG. 2009, 15, 158.

9. Muryati, Hasyim.A, Riska., Preferensi Spesies Lalat Buah terhadap Atraktan Metil Eugenol dan Cue-Lure dan Populasinya di Sumatera Barat dan Riau. J. Hort., 2008, 18(2), 227-233. 